\section{ACRLs}

Partuers in

Higber

Education

\title{
Communicating with higher education in the digital age
}

\author{
By William Miller, Thomas E. Abbott, Althea Jenkins, \\ Jonathan Lauer, and Jill B. Fatzer
}

\section{ACRL shares its experiences with bighered}

(2) ne of ACRL's key strategic goals is to reach out to the broader higher education community, sharing its programs, exchanging literature, anc collaborating on issues of mutual interest. This year, ACRL has been extremely successful in increasing its visibility among higher education organizations, including the American Association of Higher Education (AAHE), the New England Association of Schools and Colleges (NEASC), the National Association of State and University Land-Grant Colleges (NASULGC), the North Central Association of Colleges and Schools (NCA), and the Middle States Commission on Higher Education. In this issue, we share with you some of the highlights of our activities.-Althea Jenkins

\section{Improving distance learning through technology}

As part of our response to Goal 2 of ACRL's Strategic Plan (increasing contact with other higher education associations and professionals), members have been active this year in making presentations at the meetings of higher education organizations outside the field of librarianship. One such presentation was a recent half-day preconference workshop on the role of librarians in distance education, held during the American Association for Higher Education annual meeting in Washington, D.C., on March 15, 1997.

This workshop, entitled "Improving Distance Learning through New Applications of Technology," provided the audience of 53 deans, provosts, and teaching faculty from various fields with an idea of how libraries fit into the picture as academic institutions move toward distance, asynchronous learning. William Miller's introductory remarks stated that the new modes of distance education reinforce and enhance traditional roles which librarians have always played as facilitators, coaches, and teach- ers. Indeed, in the distance education world, librarians are sometimes the only highereducation professionals with whom students interact. Miller cautioned the audience that most research-quality information is not yet available electronically, so distance library services are often a matter of providing access to traditional printed resources.

Ann Coder, librarian at the Virginia Campus of George Washington University (GWU), described in detail her experiences providing library services to business executives and other adult and clistance learners, chiefly in GWU's graduate and professional programs at the Virginia campus. Coder's work is focused on the evolving "virtual" library and the new role librarians must play in helping students develop into skilled information managers.

Carol Moulden, coordinator for off-campus library services at National-Louis University (NLU) in Evanston, Illinois, discussed her work providing library services to NLU's distance learners in Illinois and six other states. The

William Miller is president of ACRL and director of libraries at Florida Atlantic University, e-mail: Miller@ACC.FAU.EDU; Thomas E. Abbott is dean of learning resources and university development at the University of Maine at Augusta, e-mail: tabbott@maine.maine.edu; Altbea Jenkins is ACRL executive director, e-mail: ajenkins@ala.org; Jonathan Lauer is director of the Leaming Resources Center at Messiab College, e-mail: jlauer@messiab.edu; Jill B. Fatzer is dean of library services at the Iniversity of New Orleans, e-mail: jbfis@uno.edu 
emphasis is on electronic access to information resources and the clelivery of materials clirectly to students' homes. She expressed strongly that her institution takes full responsibility for the library needs of its students, regardless of physical location.

Thomas Abbott was the organizer of the program and, after his presentation on distance education and off-campus library services in Maine, his home state, concluded the program by leading an hour-long, spirited group discussion on a variety of distance education issues, including the definition of an educated student, whether we can truly educate students through electronic and distance education, and whether a lab science can satisfactorily be taught this way.

A shortened version of this preconference session was presented during the regular conference, with ACRL executive director Althea Jenkins moderating. At both sessions, we shared with the audience the draft of the newly revised "Guidelines for Extended Academic Library Services" as printed in the February 1997 issue of CERI. News, and discussed the evolving role of librarians in off-campus library services, particularly as information transmitted via technologies takes hold and becomes a primary and unmediated source of information for the user.-William Miller and Thomas E. Abbott

\section{ACRL helps regional accrediting associations explore library issues}

Regional accrediting associations have a renewed interest in assessing libraries contribution toward achieving campus missions. New teaching and learning strategies such as information literacy and distance education are areas where libraries have major implementation roles and have exhibited leadership. ACRL recently presented five programs on library topics and issues at the annual meetings of two accrediting associations.

On December 5, 1996, at the annual meeting of the New England Association of Schools and Colleges (NEASC) in Boston, Thomas Abbott, dean of learning resources and university development, University of Maine at Augusta, presented a preconference titled "A Vision for Information Literacy in Higher Education." The preconference used the results from a survey on information literacy that was conducted by ACRL in fall 1995 to expand understanding of information literacy and provicle a forum for dialogue with individuals who were already working with the concept and promoting learning and experience goals for students. In addition to Abbott, other panelists included: M. Beverly Swan, provost and vice-president for academic affairs, University of Rhode Island; Richard Pattenaude, president of the University of Southern Maine; and Ann Schaffner, associate director of the Science Library and reference services, Brandeis University. The preconference was designed for an audience of 20-25, but attracted 80 people.

The North Central Association of Colleges and Schools (NCA) invited ACRL to develop a program track for its annual meeting in Chi-
Cago, April 19-22, 1997. ACRL presented four programs that challenged higher education decision-makers to take a fresh look at how their campus library resources can help them achieve campus priorities in instruction, research, and service. Each program dealt with the changing roles of libraries and attracted an audience of more than 150 attendees.

The programs and their presenters were:

- "Assessing Libraries in Support of Campus missions," Elaine Didier, director of academic outreach, University of Michigan, Ann Arbor; Bernie Fradkin, dean of learning resources, and Walter l'ackard, vice-president, College of Dupage.

- "Information Literacy: General Education for the 21st Century," Patricia Breivik, clean of libraries, and Lynn Sutton, director of the Unclergraduate Library and off-campus library services, Wayne State University.

- "Off-Campus Courses and Library Support," Thomas Abbott, dean of learning resources and university development, University of Maine at Augusta; Carol Moulden, coordinator of off-campus library services, $\mathrm{Na}$ tional-Louis University; and Jerilyn Marshall, acting library director, Northwestern University Chicago Campus.

- "Assessing the Library: What Data Institutions Need," Althea Jenkins, ACRL executive director, and Stephen Spangehl, NCA associate executive director, led an audience of more than 100 participants in a discussion about the kinds of data institutions collect as evidence of the library's contribution to campus missions.Althea Jenkins 


\section{Facing the challenges of the day}

Some 200 participants attended this year's 8th Annual Information Technologies Workshop in Pittsburgh, cosponsored with the Council of Independent Colleges (CIC), CAUSE, EDUCOM, and the Consortium for Computing in Undergraduate Education (C-CUE). Most attendees were computing professionals; upperlevel academic administrators were also wellrepresented, including deans, provosts, and even a few college presidents. Librarians represented about five percent of the group.

The sessions, both plenary and breakout workshops, focused on three questions:

1) How can we understand the role of inclependent colleges and universities in the Information Age?

2) How can we identify and share effective practices to improve learning and aclministration?

3) How can we build and maintain a technological infrastructure?

It became evident that these questions center around three emerging realizations or foci. In one way or another, all the sessions I attended interfaced with the following themes.

1) Mission-driven technology, not a technology-driven mission. It is imperative that each institution first know and articulate its unique niche and mission in higher education to determine what technologies are appropriate for and best serve that institution.

2) "Field of Technological Dreams" voices must be disregarded. The "if you put it on their clesks, they will use it" paradigm was probably never clearheaded. Now more than ever we must listen to our users, hear what they need to do, and then give them technology to do it.

3) The pedagogical revolution marches on. Educational theory and practice continue to move from a professor/teaching-centered approach to a student/learning-centered paracligm. The "sage on the stage" has increasingly become the "guide by the sicle." The ongoing implications of this for the application of appropriate technology must be thought through.

The usual array of vendors beclazzled attendees with new software in hands-on sessions such as "Interactive Computer-Based Training for Staff, Faculty, and Students." Workshops addressed a broad range of relevant, dayto-day challenges, including network development, distance learning, electronic portfolios for ability-based curricula, and faculty development. One such offering related a program in Ohio based on the late Ernest L. Boyer's Scholarsbip Reconsidered, specifically the scholarship of integration.

Participants were reminded that similar institutions face startlingly similar challenges. The reassurance that others are also daunted yet invigorated by the rapid change of our time has both theoretical and practical benefits. As CIC senior associate Edward J. Barboni reminded attenclees, the human factor is, in the end, the one unchanging constant that spells success or failure, joy or sorrow.-Jonathan Lauer

\section{NASULGC offers forum on information technology policy issues}

The National Association of State Universities and Land-Grant Colleges' (NASULGC) membership includes 192 public research universities, including all land-grant institutions. Its purposes inclucle representation of the interests of these institutions to state and federal lawmakers and agencies. There are, of course, many other organizations seeking to make the interests of higher education effective in Washington. Graham Spanier, president of Pennsylvania State University and recently named chair of NASULGC's Commission on Information Technologies, feels that higher education would be better served in the contentious area of information technology policy if there were one lead agency, and if all the interested constituencies could reach consensus to "speak with one voice."

To that end, NASULGC's president, C. Peter Magrath, hosted a meeting on January 29 to which representatives of the presidentially based associations, such as the American Association of Universities and the National Association of Independent Colleges and Universities, plus a variety of national associations with significant interests in information technology, such as the Coalition for Networked Information, the Association of American University Presses, and the Association of Research Libraries were invited. Some 30 persons represent- 
ing 17 organizations attended and agreed that there was enough common ground to proceed. It was agreed that NASULGC would facilitate the development of a common agenda. Each of the six presidentially based associations will designate one college or university president to serve on a Presidents' Policy Board on Information Technology to define and promulgate policies on information technology issues and serve in an advisory role to the organizations they represent. A forum will be convened and repeated annually so that practitioners in information technology arenas and their associations may shape and inform the policies to be adopted.

The first Forum on Information Technology Policy Issues was held in Washington on March 6 and was attended by 38 delegates comprised of university presidents, chief information officers, librarians, computing center clirectors, distance education administrators, university press directors, and several association staff members. Librarians attending included ACRL's representative, Jill Fatzer, and ACRL members Elaine Albright and Sharon Hogan, who sit on NASULGC's Commission on Information Technology; also attending were Lynne Bradley from the ALA Washington Office and Pru Adler from ARL. After remarks from Magrath and Spanier on the forum's purposes, facilitator Grant Thompson led the group through an exercise to identify the most essential topics on which consensus policies will be identified. After much discussion, the areas agreed upon were copyright, clistance education, Internet enhancements, and telecommunications. Each area was assigned to a small group representative of all constituencies for the purpose of iclentifying principles on which there is substantial consensus, areas in which some negotiating might produce consensus and principles on which consensus was not possible. Each group spent several hours working up a group of principles in its area, and most found a remarkable consensus, considering the diverse interests represented.

There followed a reconvening of the entire group, which went through every draft principle to indicate whether the organization each represented could buy into it. Some redrafting occurred at this point. At the end of the day the only areas of disagreement were on subsidized telecommunications, and some aspects of fair use caused concern to the university press representatives. The next step will be a polish- ing of the statements and their presentation in a coherent document. This draft will go to the Presidents' Policy Board on Information Technology for acceptance and presentation to the associations and institutions it represents. Ultimately, the result of the effort should be more understanding of information policy issues among university presidents generally, and a clearer presentation of agreed-upon positions by many diverse associations as issues arise in Washington. Personally, it was very gratifying to see ACRL have a voice in such a potentially far-reaching endeavor.-Jill B. Fatzer

\section{(Endouments cont. from page 393)}

Since the primary purpose of the ALA general endowments is to enable ALA to respond to emergency situations, and since the present purpose of ACRL's large mandated operating reserve is essentially the same, the Budget and Finance Committee and the Board believe it makes sense to transfer to the ACRL endowments the funds in the operating reserve that have been held for more serious emergencies.

We expect that the investment income that will be produced from the larger endowments that result from the transfer will substantially strengthen the financial resources of ACRL over the long term. Modest income from the ACRL endowment will also be available to support ACRL's strategic initiatives, fulfilling to a significant extent our long-term goal for the ACRL endowment.

In view of these considerations, in San Francisco the ACRL Board will act on the following specific reconmendation from the Budget and Finance Committee:

1) that ACRL move $\$ 400,000$ from its operating fund balance and $\$ 200,000$ from Cboice's operating fund balance to the ACRL and Cboice endowments in four phased transfers over a two-year period;

2) that ACRL endowment policy be revised to conform to ALA endowment policy by including the purpose of providing financial resources that will enable ACRL to respond to emergency situations and urgent needs; and

3) that the mandated operating reserve for both ACRL and Choice be lowered to $20 \%$ of recent operating expenses.

We anticipate that this new way of maintaining our endowments and our reserves will enhance ACRL's finances and programs significantly in future years. 


\section{BUILDING INTELLIGENT SYSTEMS FロR YロUR WDRLD DF INFDRMATIDN.}

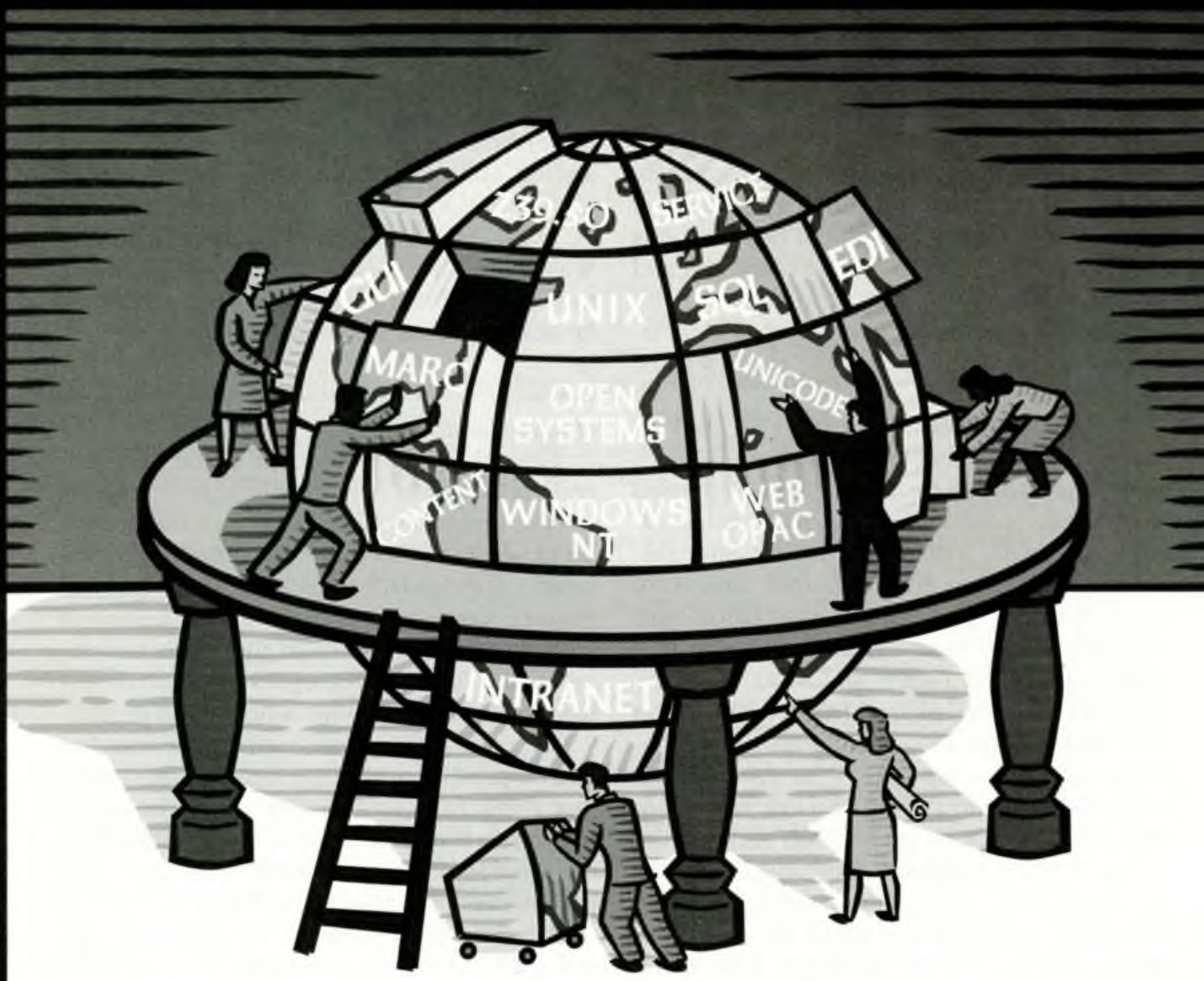

It's challenging being a librarian in the 90 's - trying to fit all the technology pieces together for the future.

But EOS International is here to help. Our scaleable library software is being used in all types of libraries around the world. The standards you need for tomorrow are built into our software today. EOS systems architecture is open and portable. Searching modules use intuitive navigation, hyperlinks, and other third-generation tools to connect you and your users to the world of information.

Though our name is new, we have been working with librarians like you for over fifteen years. We are helping over 6,500 libraries worldwide put the pieces together. Why not yours?

800-876-5484 FAX 760-431-8448 www.eosintl.com

ELECTRONIC ONLINE SYSTEMS INTERNATIONAL CARLSBAD LONDON

5 INGAPORE

BOSTON

PARIS
- WEB/OPAC

- Cataloging

- Circulation

- Serials Control

= Acquisitions

n Electronic Journals

* Service \& Training

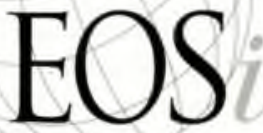

INTELLIGENT SYSTEMS... BY DESIGN 